\title{
Non-timber Forest Products Enterprise Development: Regulatory Challenges in the Koshi Hills of Nepal
}

\author{
Subash C Kunwar*, Abdul S Ansari*, and Harisharan Luintel** \\ *Livelihoods \& Forestry Programme (LFP), Nepal \\ **ForestAction Nepal \\ Corresponding author: kunwar.subash@gmail.com
}

\begin{abstract}
Nepal's government policies recognise Non-Timber Forest Products (NTFPs) enterprises as one of the potential means to contribute to poverty reduction. In practice, however, there are only a limited number of NTFPs enterprises that have been successful in creating income and employment for the poor. Drawing on the experience of promoting NTFPs enterprises in the Koshi Hills, this paper demonstrates that there are a number of regulatory issues and practical challenges that deter key processes of NTFPs enterprise development, including enterprise registration and operation, marketing and trade, taxation, and private sector investment. The paper also explores directions of policy change and possible strategies. It is argued that the proactive involvement of civil society groups, including the networks of forestdependent people, is important in addressing the local level policy challenges and influencing national policy and regulations.
\end{abstract}

Key words: community, trader, policy, taxation, management, marketing

\section{INTRODUCTION}

Since Nepal's government policy recognises Non-timber Forest Products (NTFPs) enterprises as one of the potential means to contribute to poverty reduction, there is a growing optimism on the potential of community-based NTFPs enterprises for improving rural livelihoods in Nepal. Currently, several development organisations and forestry stakeholders have taken initiatives and invested substantial resources to develop and implement strategies to promote these enterprises. Accordingly a number of enterprises have been set up in the rural areas in recent years. However, there is limited success achieved so far and the outcome has remained far below the expectation. The economic value of community and governmentmanaged forests is not harnessed to their potential, as traders export unprocessed NTFPs to India with little revenues or incomes.

While government policy is generally considered a decisive factor for enterprise success, there is still limited understanding about how it actually influences the success of the enterprise. In this context, this paper reviews government policies and its implementation mechanisms to find out how the policy works in determining success or failure of NTFPs enterprises. Drawing on the experience of the Koshi Hills of Nepal, our analysis shows that policy affects enterprises' functioning through creating difficulties in the production and/or supply of raw materials, their processing, and the marketing of the semiprocessed and/or final commodities. It shows that unfavorable government policies and regulatory framework remains a major barrier to the establishment and operation of NTFPs enterprises. It is also argued that without developing enterprises and attracting private investment in forestry sector, it is hard to generate employment for rural people.

\section{BACKGROUND}

Nepal has rich biodiversity per unit area, and this is mainly attributed to the wide network of protected areas (GoN 2002). About $150 \mathrm{~km}$ of North-South and $800 \mathrm{~km}$ of East-West expanse of the country hosts a wide range of geographic, climatic, floral and faunal variations. There are more than 700 plant species that have 
medicinal value, of which 238 are in active use and 100 are traded. The government has identified 30 species in priority list, of which 12 are for commercial cultivation and market promotion (AEC/FNCCI 2004, Subedi 2006, Shrestha and Das 2008). NTFPs are increasingly gaining popularity in national and international markets as they have been used as medicines and as important ingredients to several consumer items, such as cosmetics, tea, and food. It is widely agreed that NTFPs could be a very important commodity in Nepalese economy. A survey of NTFPs producers, traders and processers from the eastern border of Nepal to the mid-western town of Nepalgunj shows that a total of 100 entrepreneurs handled 42 thousand tons of over 100 different NTFPs items, equivalent to USD 26 million (Subedi 1997). It is estimated that about 10,000 to 15,000 tons of plant products of more than 100 species are exported to India annually, and it comprises 90 percent of total NTFPs trade (Edwards 1996).

While NTFPs are very important to the rural livelihoods and national economy, these resources have been under serious threat due to increase in human pressure. Certain plant species are already on the verge of extinction because of unsustainable harvesting. This has called the attention of the conservation and forestry organisations, professionals, practitioners and the scholars, who argue that the concerns of NTFPs conservation, management, harvesting, processing, and use need to be brought in the centre of the development discourse (Belcher et al. 2005, Subedi 2006). Recently, the governments of several developing countries, including Nepal, received pressure to formulate polices in order to promote NTFPs resources. Given this new attention, forest policies in Nepal during the past two decades have put certain level of emphasis on NTFPs (Banjade and Paudel 2008).

Reflecting on the experiences of the nationalisation of forest, the government realised the importance of local people's participation in the management of forest and formulated a participatory forestry policies in
1978 in the form of Panchayat Forest and Panchayat Protected Forest. These policies facilitated to hand over patches of government forest to local political unit, called Panchayat, for the conservation and management of forest within the political unit. After a decade, however, the Master Plan for the Forestry Sector (MPFS) placed considerable emphasis on ensuring forest dependent people's participation in forest management. Subsequent forestry policy, viz. the Forest Act 1993 and Forest Regulation 1995, has been enforced as a legislative measure. The policy is lauded as highly successful model in participatory and sustainable forest management in Asia and elsewhere.

The Community Forestry (CF) intervention has raised a sense of ownership over forest resources amongst the rural people. However, the potential of CF to create income is not fully realised. In particular, the wide range of NTFPs found in CF is yet to be promoted through community-based enterprises. Often local communities lack technical knowledge and institutional capacity to harness NTFPs and other forest products. Success of communitybased forest enterprises depends upon the degree to which policy environment facilitates the development of entrepreneurship, market access, appropriate technology, and business services.

In line with the national policy, the government established seven gene banks (plant resource conservation and management areas) and invested in the development and extension of medicinal and aromatic plant processing technology during the tenth plan period (20022007). Similarly, in the fiscal plan 2008/09, the government has considered agriculture sector reform as a priority and the budget statement recognises the significance of foreign exchange earnings generated from the export business by forest and agro-based industries. In addition, the promotion of herb cultivation in public land for poverty reduction as a campaign has been planned. Funds are also allocated to produce 11.5 million seedlings of medicinal herbs, bamboo, cane and fodder. A plan to establish a 
Table 1: Types of NTFPs Enterprises in the Koshi Hills

\begin{tabular}{|c|c|c|}
\hline SN & District & Commodities produced by the enterprise \\
\hline 1 & Dhankuta & $\begin{array}{l}\text { - Essential oil } \\
\text { - Bel squash } \\
\text { - Khoto } \\
\text { - Briquette }\end{array}$ \\
\hline 2 & Sankhuwasabha & $\begin{array}{l}\text { - Lokta handmade paper } \\
\text { - Allo } \\
\text { - Laligurans squash } \\
\text { - Briquette } \\
\text { - Spices (agricultural base) }\end{array}$ \\
\hline 3 & Bhojpur & $\begin{array}{l}\text { - Lokta handmade paper } \\
\text { - Bel squash } \\
\text { - Briquette } \\
\text { - Spices and vegetable (agricultural base) }\end{array}$ \\
\hline 4 & Terhathum & $\begin{array}{l}\text { - Chiraita } \\
\text { - Ginger }\end{array}$ \\
\hline
\end{tabular}

herb processing center in Karnali zone is also prepared to effectively harness the potential of biodiversity, the fiscal policy has also adopted the strategy of 'one area-one species'.

So far, limited number of NTFPs enterprises are established in Nepal. Subedi (2006) reports that over 161 plant species are harvested for commercial transaction, and that at least 137 entrepreneurs are engaged and about 71 community-based enterprises are operating in Nepal. In the Koshi Hills community-based NTFPs enterprises on a few commodity types have emerged (Table 1).

\section{SYNOPSIS OF GOVERNMENT POLICY}

Before 1926, forest had been taken as granted and the government encouraged converting forest into agricultural land. In 1957, the government brought a policy to nationalise private forest. Then the local people no longer felt ownership over nearby forest which caused rampant deforestation. To correct this mistake to alienate people from the forest, government brought participatory forestry policies in late seventies. Currently, Nepal's forestry sector operates under a complex policy environment that comprises: a) national level sectoral policies; especially the acts, regulations, directives, guidelines, and circulars; b) cross sectoral laws and policies, including the fiveyear periodic plans; and c) international conventions and treaties (Table 2). All these policies are relevant to the enterprising on NTFPs in Nepal.

Table 2: National Policies and International Treaties and Conventions Relevant to NTFPs Enterprises Sectoral laws and policy

- Master Plan for the Forestry Sector 1988

- Forest Act 1993

- Forest Regulation 1995

- Community Forestry Directive, 1996

- Collaborative Forest Management Guidelines, 2003

- NTFPs Policy 2004
Cross-sectoral laws and policy

- The Industrial Enterprise Act 1992

- The Company Act, 1997

- The Cooperative Act 1992

- The Income Tax Act 2002

- The Value Added Tax Act 1996

- Environment Protection Act 1997

- Environment Protection Rules, 1997

- Local Self-Governance Act, 1999

- Food Act, 1966

- $10^{\text {th }}$ Five-year Plan
Treaties and conventions

- Treaty of trade between Government of Nepal and The Government of India 1991

- Convention on International Trade in Endangered Species of Wild Fauna and Flora (CITES) 1973

- Treaties under the World Trade Organisation

- Convention on Biological Diversity 1992 
Among the policies and laws identified in Table 2, a few have greater implication and a more direct bearing on enterprise development activities. These policies and laws, along with their major focus, are presented in Table 3.

Table 3: Major Forest Policies and Legislations and their Major Focus

\begin{tabular}{|c|c|}
\hline Forest policies and legislation & Major focus \\
\hline $\begin{array}{l}\text { Master Plan for Forestry Sector } \\
1988\end{array}$ & $\begin{array}{l}\text { - Community forestry and forest conservation } \\
\text { - Fulfilment of people's basic needs } \\
\text { - Species conservation } \\
\text { - Environmental protection for ecological balance } \\
\text { - Utilisation of forest for the benefit of people } \\
\text { - High value medicinal plants }\end{array}$ \\
\hline Forest Act 1993 & $\begin{array}{l}\text { - Ensure easier access for the basic need of local people } \\
\text { - Economic development of the people } \\
\text { - Cooperation and participation of people in conservation and } \\
\text { utilisation of various types of forests }\end{array}$ \\
\hline $10^{\text {th }}$ Five-year Plan & $\begin{array}{l}\text { - Income and employment generation } \\
\text { - Leasing scheme of NTFPs and medicinal herbs } \\
\text { - Focus and encouragement on farming of high value NTFPs } \\
\text { - Emphasis on forest-based micro-enterprises }\end{array}$ \\
\hline NTFPs Policy 2004 & $\begin{array}{l}\text { - Private sector participation for NTFPs development } \\
\text { - Emphasis on local processing } \\
\text { - Conservation and preservation of high value herbs and NTFPs }\end{array}$ \\
\hline Local Self Governance Act 1999 & $\begin{array}{l}\text { - Empower local government bodies to better regulate natural } \\
\text { resources }\end{array}$ \\
\hline Cooperative Act 1992 & - Cooperative organisations can operate forest-based enterprises \\
\hline Industrial Enterprises Act 1992 & $\begin{array}{l}\text { - Small and large-scale industry can be opened } \\
\text { - Mechanism for one-window system }\end{array}$ \\
\hline
\end{tabular}

Likewise, there are different government and private sector institutions that are responsible to facilitate NTFPs trade and export in Nepal (Table 4). Several tasks linked to NTFPs trade and export are linked to different government agencies and the private sector. And, it takes a considerable time to materialise a single transaction, as the government agencies often create administrative hassle and barrier during the documentation procedure.

Table 4: Different Government Line Agencies' Responsibilities to Facilitate NTFPs Trade

\begin{tabular}{l|l|}
\hline $\begin{array}{l}\text { Certificate and documents } \\
\text { Certificate of origin }\end{array}$ & $\begin{array}{l}\text { Concerned agencies and organisations } \\
\text { FNCCl, Nepal Chamber of Commerce }\end{array}$ \\
\hline $\begin{array}{l}\text { Export permit license } \\
\text { Ritrict Forest Office, Department of Forest and Department of Plant } \\
\text { Ruarantine certificate }\end{array}$ & Department of Forest and Department of Plant Resources \\
\hline Plant quarantine offices (under the Department of Agriculture)
\end{tabular}




\section{OVERVIEW OF EXTERNAL SUPPORT TO FORESTRY DEVELOPMENT IN THE KOSHI HILLS}

The credit of current initiatives of NTFPs development in the Koshi Hills goes back to the Koshi Hills Rural Development Project (KHARDEP) period and subsequently to Nepal UK Community Forestry Project (NUKCFP) period. In the beginning, the Community Forest User Groups (CFUGs) were provided with training to enhance their institutional capacity. These projects respectively focused on integrated development approach and on the community forestry intervention through CFUGs. While the projects made important initiation in forest resource management, they paid very little attention on NTFPs. The main objective of NUKCFP was to identify and form CFUGs and to handover the community forest. Further, the project focused on strengthening the capacity of government organisation, viz. the District Forest Office (DFO), and to support the CFUGs through the DFO.
The Livelihood and Forestry Programme (LFP), a successor program under Britain's support, started in April 2001. It builds on the experience and lessons of the NUKCFP, which was implemented for 10 years in fifteen districts of Nepal, including the Koshi Hills. The LFP aims to contribute to reduced vulnerability and improved livelihoods of the poor and excluded rural people through financial, social and technical interventions where DFO delivers technical forestry activities and local NonGovernment Organizations (NGOs) undertake social mobilization work. The programme purpose is to enhance the livelihood assets of rural communities by promoting more equitable, efficient, and sustainable use of natural resources including forest and NTFPs. The case of the establishment of a community hand-made paper enterprise in Bhojpur district provides a glimpse of how LFP works with its partners to help CFUGs create income and employment (Box 1).

Box 1: Lokta handmade paper enterprise generate income and employment

Salpathulimpa community forest is situated in the lap of mountain wetland Salpa Pokhari, Dovane VDC of Bhojpur district and is approximately 22 miles away from district headquarters. It spreads over an area of 1093.20 ha and 53 households of Sherpa and Tamang communities are managing it. LFP, DFO and the NGO named Samuhik Abhiyan have worked for the past few years to support the CFUG to manage the forest, establish an enterprise and carry out livelihood activities. DFO staff and Local Resource Persons (recruited by the NGO) worked together for several forest management and livelihood related activities. They completed forest inventory in 2008, recommended an annual sustainable harvest of $6350 \mathrm{~kg}$, and to initiate a hand-made paper enterprise. These organizations held a series of discussions with the CFUG. It has established a Lokta handmade paper enterprise and has participated in a NTFP network. The enterprise is now registered in the District Small and Cottage Industry Office. This community-based enterprise has been regularly providing employment to six community members who get a wage of approximately NRs 4500 monthly.

\section{REGULATORY CHALLENGES}

Nepal's participatory forestry policies and the activities of several organisations have made significant progress over the recent decades. However, even with a high level of people's participation within Nepal's forestry sector, forestry policies and practices are yet to deliver stated objectives of poverty reduction. There is a long way for the forestry sector to go in order to serve as an important source for generating revenue for the government and income and 
employment for the people. This section discusses the policy and regulatory challenges, especially focusing on how they have influenced the establishment and operation of NTFPs enterprises in Nepal's Koshi Hills districts.

\section{Contradictory Policies on Taxation}

Under the current policies, the central and local governments both impose tax on NTFPs trade. The Forest Act 1993 authorises the DFO to regulate and raise tax on forest products. Similarly, the Local Self-Governance Act 1999 provides local government the authority to impose local tax for those forest resources which are collected from areas within its jurisdiction. This has contradicted with the Forest Act 1993. Thus the central and local governments started to tax NTFPs trade on the basis of Forest Act 1993 and Local Self Governance Act 1999, respectively.

The central government collects royalty for the commercial collection of NTFPs from the wild and imposes tax on their trade. Similarly, the government has formulated financial regulations that need the payment of Value Added Tax (VAT) on the trade of goods and services. During export, the customs office requires an $\mathrm{HS}$ code ${ }^{1}$ or receipt of VAT payment. Without this, it does not provide permission for the export of NTFPs. Though this provision has been relaxed for the export of medicinal herbs and essences, export regulation has failed to specify and clarify under which HS code and how the exemption is to be made. Therefore, the exemption has been practically useless to the NTFPs exporters.

Similarly, multiple taxation at the district level is also prevalent in NTFPs trade. The District Development Committee (DDC) imposes tax on NTFPs in two ways. First, the DDC receives 10 percent of the total revenue that accrues to the DFO as it collects royalty. Second, it imposes certain taxes on NTFPs as per the authority under the Local Self-Governance Act 1999. In addition, when the products are transported districts traders have to pay levy at each district check post both formally and informally (bribe). The Local Self-Governance Act 1999 Article 215 provides the unauthority to the DDC to tax on NTFPs on the condition that the DDC Council approves the royalty rates. However, the Local Self Governance Regulation 2000 Annex 23 has made the contrary provision that the DDC can tax NTFPs that are produced within the district. The annex also clarifies that once a DDC takes export tax on its products, another DDC cannot charge the export tax on the same product. Though the Regulation has clarified the provisions to some extent, the ambiguity in the act has created confusion. Most of the DDCs interpret the act on their own way and impose tax on the products from another district. The Supreme Court has also given verdict in favor of DDC right to tax, with which the controversy on taxation continues.

\section{Inappropriate Royalty}

There are at least two ways of inappropriately generating royalties from NTFPs. One is the levying on the products sourced from the private and community forests, and it is against the legal provisions. The government can generate royalty only on NTFPs collected from the government forest, and not on NTFPs sourced from community forest or private land. The second is the determination of royalty rate in an ad hoc basis. Less than 20 percent of the total collection of NTFPs comes from private land and the rest from natural forests (nepalnature.com 2005 cited in Devkota 2006). However, for its own failure to determine the origin of the product, the government levies royalty also products that are collected from community forest or private land. For example, many farmers are encouraged by DFO and other organisations in the Koshi Hills to cultivate Swertia chiraita in private land but the DFO questions its origin when the farmers start selling it. Farmers have to encounter many hassles to get approval from DFO for the sale of these products. This has seriously discouraged commercial farming of Swertia chiraita in the Koshi Hills.

On the other hand, the royalty rates of important NTFPs are determined without any clear basis. A look at the royalty rates for few 
species naturally occurring or cultivated in the Koshi Hills districts (Table 5) shows that the royalty rates do not relate to the corresponding market price in any sensible way. For example, the royalty rate on Citronella, Palmarosa and Lemongrass has fixed at the same rate i.e. NRs 1 per kg However, the market price of Citronella oil is lower than that of Lemongrass and Palmarosa. Similarly, for Lokta (Daphne bholua) and Argeli (Edgeworthia gardnery) equal royalty rate has been fixed, though their final products have different prices at the market. In addition, royalty for either raw or processed materials is not mentioned clearly.

Table 5: Royalty, DDC Tax, Market Price and Export Quantity from Sankhuwasabha and Dhankuta

\begin{tabular}{|l|l|l|l|l|}
\hline Species & $\begin{array}{l}\text { GoN royalty per } \\
\text { kg NRs in raw } \\
\text { form }\end{array}$ & $\begin{array}{l}\text { DDC } \\
\text { Tax/kg of } \\
\text { product } \\
\text { NRs }\end{array}$ & $\begin{array}{l}\text { Market price of finished } \\
\text { product/kg (KTM) in } \\
\text { NRs }\end{array}$ & $\begin{array}{l}\text { Royalty as a percentage } \\
\text { of market price in NRs }\end{array}$ \\
\hline Lokta & 5 & 3.75 & 425 & 2.05 \\
\hline Argelli & 5 & 3.75 & 325 & 2.69 \\
\hline Lemongrass & 1 & 1 & 1,200 & 0.16 \\
\hline Citronella & 1 & 1 & 600 & 0.33 \\
\hline Palmarosa & 1 & - & 1,000 & 0.1 \\
\hline
\end{tabular}

Similarly, the custom office levies 5 percent duty on the market price of the NTFPs at the export point but there is no clarity about which market price it takes as base. Market prices may be either at collection point or at export point or at international markets. Practically, the custom office has been imposing tax in an ad hoc basis.

\section{Cumbersome Process for Community Forest Hand over and Enterprise Registration}

The government has now brought a new policy that requires carrying out Initial Environmental Examination (IEE) or Environmental Impact Assessment (EIA) for handing over of community forests. IEE and EIA are required if the forest to be handed over has an area over 200 ha and 500 ha respectively. These provisions have delayed the handing over process as they need more time and technical expertise. It further adds financial and other burden to local communities. This implies adverse impact in promoting community-based NTFPs enterprises at local level.

Similarly, the industries using under 5 tons of raw materials of same species within a district can simply be registered by submitting an application to the Cottage and Small Industries
Development Office/Board enclosing the specially designed "kha" form, citizenship card and consent letter from the concerned agency. Similarly, the industries using 5 to 50 tons of raw materials are considered as environmentally sensitive and they need to go through the IEE process as specified by the Environmental Protection Regulation 1998. If the industry is using over 50 tons of raw materials, it needs to submit an EIA report. The processes for conducting both IEE and EIA are complex and lengthy and therefore entrepreneurs are less interested to bear the burden of these processes.

From practical point of view, the specification of the forest regulation about the location for establishing NTFPs enterprise is generally inappropriate. There is a provision to maintain a distance between the locations of the forest and enterprise, which is at least $1 \mathrm{~km}$ in the hill and $3 \mathrm{~km}$ in the Terai. This provision severely discourages small entrepreneurs entering in the NTFPs business. This has hindered the government's own prioritised plan of NTFPs development and poverty reduction. The case in the Box 2 demonstrates how this policy frustrates the entrepreneurs. 


\section{Box 2: Government policy frustrates NTFPs entrepreneur}

Mr. Tilak Thapa invested NRs 15,00,000 to install a distillation plant at Bhedetar Dhankuta. He was very optimistic and enthusiastic about his business. He had planned to produce essential oil from Artimissia vulgaris and Cinnamomum tamala. He went to District Forest Office (DFO) to get permission but the office turned down his application as his plant location lies within $1 \mathrm{~km}$ from forest. Mr Thapa had no option to find a nearby location that is over $1 \mathrm{~km}$ away from the forest where he could relocate his plant. He was forced to close his distillation plant and suffered a heavy loss. In fact, the raw materials he was going to use would not have adverse impact on environment. Rather, if his plan worked, it would have motivated local people to cultivate the plant in their degraded lands.

\section{Ban on Export of Some Non-timber Forest Products}

The government has imposed a ban on the collection, trade and export of Dactylorhiza hatagirea and Juglans regia. Likewise, Nardostychis gradniflora, Valeriana jatamansi, Cinnmomum glaucesecens, Taxus baccata, Abies spectabilis, Rawolfia serpentina, Permilia spp, and Silajit (a mineral exudate) are banned for export in the crude form. It seems that the intention of the ban is to protect the species from over-exploitation. However, decisions to select the species to ban are not based on the scientific study but on the ad hoc decision.

In some cases, traders consider that exporting NTFPs in crude form is more profitable than in processed form. Most often NTFPs traders lack the access to the knowledge and technology for processing of NTFPs. The government does not specify the forms of processing for different species. In addition, it is also found that for some of the products like Swertia chiraita, foreign buyers do not want to pay a higher price for their processed product due to the risk of adulteration. It was also learnt from the Midwestern Region that NTFPs grading, cleaning and initial processing before the sales comprised an additional burden to local entrepreneurs, as these did not increase the income since the Indian wholesalers were reluctant to pay higher price for the graded (value added) products. Despite this, the government made the processing mandatory for certain species for their export. Such provision lack proper justification.

\section{Unsustainable Non-timber Forest Products Collection}

Officially, the DFO allows outsiders to extract timber and NTFPs from government managed forests. Anybody can get a permit from the DFO to collect NTFPs from such forests. Often more than one person is allowed to collect NTFPs from the same forest, leading to unhealthy competition by permit holders, which results in unsustainable harvest. The outside contractors have a concern on profit and on the volume of collected materials, rather than on the sustainability of the resource. Such a situation has led to NTFPs depletion (Box 3). By issuing licenses to outside contractors, the government also ignores its own policy commitment to involve local people in conservation, management and utilisation of forest resources.

\section{Lack of Government Support to Make Rural-based Enterprises Competitive}

To make investment friendly environment for the promotion of NTFPs enterprises, there is need of crucial supports other than policy. The areas include a) management, b) marketing, c) financing, d) infrastructure development, and e) technological innovations. To coordinate and synthesise all factors of production effectively and efficiently, entrepreneurs need management knowledge and skill. Equipping rural entrepreneurs with critical management knowledge and skills is one of the key needs in the promotion and development of NTFPs enterprises at present (Luintel et al. 2004). 


\section{Box 3: NTFPs depletion causes trouble for producers}

Bishnu Maya B.K., the resident of Okhre village in Tamafok VDC ward No. 9 has a 8-member family that lives on subsistence, which is based mainly on forestry and agriculture. The family holds 30 ropani of land where they grow corn, potato, ginger and turmeric. The household has a pair of oxen, a buffalo, a goat and few chickens. The family is worried about the decrease in land productivity and a subsequent reduction in family food supply every year. They produce food sufficient only for six months and for the rest they have to manage from alternative means. Bishnu Maya planted Chiraita in a small patch of land in 2007 and harvested about $7 \mathrm{~kg}$ in dry form. Besides this, her family collects Chiraita from nearby national forest and sells to local buyers every year. Few years ago, she collected $10 \mathrm{~kg}$ Chiraita per day, but in recent years she can hardly collect 2 to $3 \mathrm{~kg}$. When the government allowed private collectors to harvest Chiraita from the forest, Chiraita availability has been dropped sharply. Thus, her family income has decreased, and as a result they have to depend on wild grass and root when food becomes scarce. She knows that Chiraita does not become mature enough to harvest in October but she is compelled to collect premature Chiraita. If she does not collect it somebody else would already have collected it. The prematurely harvested Chiraita fetches lower price because of poor quality. Bishnu Maya fears that Chiraita would completely disappear if the present collection practice continues.

Generally, the rural/community-based enterprises produce goods and services without market assessment. With a lack of market information and an understanding the dynamics of the market, the rural NTFPs entrepreneurs follow the conventional marketing strategy. They become uncompetitive in the market and unsuccessful in the long-run, as they do not know changing market environment and have little bargaining power. Besides, NTFPs marketing channel is too long in the Koshi Hills and the business is captured by some key market players who have good relations with the Indian traders. These players also control the flow and price of NTFPs at the local level. The government has not taken any initiative to end the monopoly of such traders, which would require making market information transparent and widely accessible. Similarly, the unequal treaty with India has also caused various difficulties in NTFPs trade. There are certain restrictions posed by Indian government while exporting NTFPs to India. In addition, NTFPs trade is largely informal and that bribery is rampant. Support activities to encourage NTFPs trade and enterprise development are limited and many hassles exist in collection, trade and enterprise development (Edwards 1996, $\mathrm{AEC} / \mathrm{FNCCl}$ 2006).

Community-based NTFPs enterprises have not been the priority sector for the financial institutions. There is no government policy to promote these institutions to invest in NTFPs business. Financing is one of the major problems for the community-based NTFPs enterprise development in Nepal. Particularly in the Koshi Hills, the perceptions of financial institutions on community-based NTFPs enterprises are not favorable (Box 4).

Box 4: Perceptions of financial institutions towards NTFP enterprises in the Koshi Hills

- NTFP enterprises are not sound in terms of business plan and enterprise management

- NTFP enterprises have poor knowledge of market

- NTFP enterprises have incapable management committee to pool and access available financial resource

- NTFP enterprises have poor performance

- NTFP enterprises are established even when adequate and well developed infrastructure facilities such as telephone, road, electricity, communication are lacking

- Most of the NTFP enterprises are established in remote areas where financial institutions are not interested to invest

- Fiscal policy of government is unfavourable to the promotion of NTFP enterprises. 
Another main reason for poor financing is that most of the community-based NTFPs enterprises lack property to keep as mortgage to access loan from the bank. Moreover, the higher interest rates and rigid investment policies of the financial institutions also discourage the rural community-based NTFPs entrepreneurs to take loan.

Availability of physical infrastructure facilities such as road, transport, electricity and communication are the prerequisites and prime conditions for the establishment and successful operation of NTFPs enterprises. Some of the enterprises are established in Terai region where such facilities are available. However, most of the high-value NTFPs are found in high hills and mountain regions where basic infrastructure facilities have not been built yet. Therefore, the established enterprises and the producers/collectors of the NTFPs in the Koshi Hills have been bearing higher cost for NTFPs collection and processing. For example, to deliver the Lokta handmade paper from Sankhusabha district to Kathmandu, the producer has to pay to NRs $35 / \mathrm{kg}$ (airfare) resulting into low profit.

Most of the NTFPs enterprises based in the Koshi Hills use the technologies that are inappropriate, old, obsolete and cumbersome. This is partly due to entrepreneurs' choice based on limited information and partly due to the unavailability of locally suitable technology. The wrong choice of technology has hindered the business. The government has not been able to introduce innovative programme for the development of new technology. In addition, the government neither has given facilities in custom duties and tax to import the technologies nor has initiated a programme of research and development of new technology. Due to the old and poor essential oil technology in Dhankuta, oil productivity is low. Improper technology raises production cost and hinders product quality and diversification. For example, the Tenjure handmade paper is unable to diversify its products such as to produce envelopes, file and decorative items. Likewise, most of the essential oil processing enterprises in the Koshi Hills are confined to produce only citronella oil and are not able to use other aromatic plants.

\section{Limited Civil Society Influence}

There are only few membership-based civil society organisations working in policy advocacy in the forestry sector of Nepal. These include Federation of Community Forestry Users, Nepal (FECOFUN), Community Forestry Supporters' Network (COFSUN), and Himalayan Grass Roots Women's Association for Natural Resource Management (HIMAWANTI). Civil society organisations lack technically competent personnel to influence policy processes (pers. comm. Bal Bahadur Rai, FECOFUN Central Committee Member). Huge and very formal institutional set up and the rapidly changing agenda of FECOFUN are some of the limiting factors to develop professional members to work for long-term policy advocacy. Similarly, very few research institutions are involved in NTFPs development in Nepal. These organisations are not able to influence the policy formulation and enforcement in a way to promote NTFPs enterprises development. The government agencies become opaque and less participatory in policy formulation. Availability of financial and human resource is one of the important factors to influence natural resource policy processes and the resource-crunch has been one of the main limitation for these civil society organisations to carry out policy advocacy activities. Therefore, the civil society perspectives have not been reflected properly in the policy.

\section{Limited Incentives to Private Sector Involvement}

The private investors get attracted to areas where they see profit, including a hassle free business environment, low establishment cost, availability of basic infrastructure and easy access to market and information. However, such environment is a distant possibility and the investors are not encouraged to NTFPs enterprises. Though the government has made provision of 'one window system' to provide the various services to make environment 
conducive to the investors, the establishment of NTFPs enterprise has many hassles pertaining in the process of registration, operation and marketing the products. Such hassles discourage potential investors to invest on NTFPs. Investors also lack information to enable them make investment decisions, as very little research and documentation is available. Similarly, intransparent market and its complex and hidden channel put the investor at risk.

Reluctance of non-local and larger private investors to invest in NTFPs enterprise is also due to the confusions of resources ownership and the lack of confidence between local community and them. Without commercial farming of the NTFPs that sustainably supply the raw materials in adequate quantity, there is high risk for investors to enter into NTFPs business. The poor level of infrastructure and banking facilities further restrict the private sector to grow.

\section{CONCLUSION}

Though several studies have explored the problems and prospects of community-based NTFPs enterprises in Nepal, few have analysed how policies, legislation and institutions influence the operation of enterprise on the ground. This paper has provided an account of how a wide array of regulatory challenges affects community-based NTFPs enterprises in the Koshi Hills. Despite some favorable policies developed in the recent years, policy and regulatory constraints continue to remain a major hurdle to the growth and development of NTFPs enterprises in Nepal. The reasons are two-fold. On the one hand, the policies are still restrictive, and on the other, even the enabling aspects of policies get distorted in practice. There are some inherent flaws and lacuna in government's operations where formulated policies and legislation are not implemented according to their true spirit (Parajuli and Luintel 2006).

The experience from the Koshi Hills shows that most of the problems on the development of NTFPs enterprise lie at the district level where policies often get misinterpreted. The government continues to see policy formulation as its own sole job, without engaging concerned and civil society groups. The practices of impact assessment, feedback mechanism and policy review are yet to evolve in order to capture the insights from the ground level. Local NTFPs entrepreneurs find regulations unclear and ambiguous, and contradictory. The entrepreneurs also have to pass through lengthy bureaucratic formalities and red-tape to establish an enterprise. There is also a lack of coordination among various government organisations related to forestry enterprise regulation.

Enabling business environment and business services are the crucial factors to boost up community-based enterprises but investors see a lack of investment-friendly environment in the NTFPs sector. In fact, the rural investors are micro entrepreneurs with little capital investment and they generally do not set up a business without outside assistance, both in terms of finance and technology. Despite restrictive regulatory environment, there are some cases of successful NTFPs enterprises in the Koshi Hills. But their success is questionable in the long-run given the unfavorable business environment that prevails in the forestry sector.

Clearly, development of NTFPs enterprises can take momentum only if the policy environment is conducive and all regulatory bottlenecks are removed. One specific direction for policy change could be to remove ambiguous and restrictive policies. While this can have positive effect on enterprise registration and operation, there is also a need to provide services by targeting the small scale and pro-poor NTFPs enterprises. Tax and fiscal incentives should enable the private sector to invest on forest products. Another option is to take corrective measures, which include amending a number of specific regulatory provisions, especially on licensing, enterprise registration, exporting after processing, and verification. This will encourage local entrepreneurs in rural areas. 


\section{REFERENCES}

AEC/FNCCI 2004. Trade Pattern of Non-Timber Forest Products in Jumla, Surkhet and Nepalgunj: Appropriate Policy Measures for Business and Trade Enhancement, Federation of Chambers of Commerce and Industry. Kathmandu: Agro Enterprise Centre.

Banjade, M.R. \& Paudel, N.S. 2008. Economic Potential of Non-timber Forest Products in Nepal: Myth or Reality? Journal of Forest and Livelihood, 7(1): 36-48.

Belcher, B., Ruiz Perez, M. \& Achdiawan. R. 2005. Global Patterns and Trends in the Management of Commercial NTFPs: Implications for Livelihoods and Conservation. World Development, 33(9).

Devkota, B.P. 2006 . Medicinal and Non-timber Products: Basis for social and Economic Development. In: R. Shrestha, B.R. Kandel and B.P Devkota (Eds.), Hamro Ban (F.Y. 2061/2062) (Our Forest - F.Y. 2004/2005). Kathmandu: Department of Forest.

Edward, D.M. 1996. Non-timber Forest Products from Nepal: Aspects of the Trade in Medicinal and Aromatic plants. Babarmahal, Kathmandu: Forest Research and Survey Center, Ministry of Forests and Soil Conservation.

GoN 2002. Nepal Bio-diversity Strategy. Kathmandu. Ministry of Forest and Soil Conservation.

Luintel, H., Banjade, M.R., Neupane, H.R. \& Pandey, R.K. 2004. Issues of Sustainable Nontimber Forest Product Management and Ways
Forward. In: K.R. Kanel, P. Mathema, B.R. Kandel, D.R. Niraula, A.R. Sharma and M. Gautam (Eds.), Twenty Five Years of Community Forestry: Proceedings of the Fourth National Community Forestry Workshop. Kathmandu, Nepal: Community Forestry Division, Department of Forest. [pp. 42-47]

Parajuli, D.P. \& Luintel, H. 2006. Non-timber Forest Products Development Policy 2005: An Analysis. Hamro Ban Sampada (Our Forest Resources - in Nepali), 3(1): 7-13.

Shrestha, P.R. \& Das, P.K. 2008. Critical Review of Policy Issues and Strategic Vision Related to Sustainable Harvesting Transportation and Trade of NTFPs in Nepal. A Paper Presented in the National workshop on 'Non- Timber Forest Products and Medicinal Plants based Enterprise Development Opportunities and Challenges' Organized by Nepal Foresters' Association, 20 Feb, 2008. Kathmandu: Micro - Enterprise Development Program, UNDP and Government of Nepal.

Subedi, B.P. 1997. Utilization of Non-timber Forest Products: Issues and Strategy for Environment Conservation and Economic Development. A theme paper for the workshop on the Utilization of NTFPs for Environmental Conservation and Economic Development in Nepal, March 29, 1997. Kathmandu: Asia Network for Small Scale Bioresearches.

Subedi, B.P. 2006. Linking Plant-Based Enterprises and Local Communities to Biodiversity Conservation in Nepal Himalaya. New Delhi: Adroit Publishers.

\footnotetext{
1 The HS CODE (Harmonised Commodity Description and Coding System) of tariff nomenclature is an internationally standardised system of names and numbers for classifying traded products developed and maintained by the World Customs Organisation (WCO) (formerly the Customs Co-operation Council), an independent intergovernmental organisation with over 170 member countries based in Brussels, Belgium.
} 